\title{
Acute Health Impacts of the Southeast Asian Transboundary Haze Problem-A Review
}

\author{
Kang Hao Cheong ${ }^{1, *(\mathbb{D})}$, Nicholas Jinghao Ngiam ${ }^{2}{ }^{\mathbb{D}}$, Geoffrey G. Morgan ${ }^{3}$, Pin Pin Pek ${ }^{4,5}$, \\ Benjamin Yong-Qiang Tan ${ }^{2}$, Joel Weijia Lai ${ }^{1}$, Jin Ming Koh ${ }^{1}$, Marcus Eng Hock Ong ${ }^{4,5}$ and \\ Andrew Fu Wah Ho 6,7,8 (D) \\ 1 Science and Math Cluster, Singapore University of Technology and Design, Singapore 487372, Singapore \\ 2 Division of Neurology, Department of Medicine, National University Health System, \\ Singapore 119074, Singapore \\ 3 School of Public Health, The University of Sydney, Sydney, NSW 2006, Australia \\ 4 Department of Emergency Medicine, Singapore General Hospital, Singapore 169608, Singapore \\ 5 Health Services \& Systems Research, Duke-NUS Medical School, Singapore 169857, Singapore \\ 6 SingHealth Duke-NUS Emergency Medicine Academic Clinical Programme, Singapore 169857, Singapore \\ 7 National Heart Research Institute Singapore, National Heart Centre, Singapore 169609, Singapore \\ 8 Cardiovascular \& Metabolic Disorders Programme, Duke-NUS Medical School, Singapore 169857, Singapore \\ * Correspondence: kanghao_cheong@sutd.edu.sg
}

Received: 20 August 2019; Accepted: 29 August 2019; Published: 6 September 2019

check for updates

\begin{abstract}
Air pollution has emerged as one of the world's largest environmental health threats, with various studies demonstrating associations between exposure to air pollution and respiratory and cardiovascular diseases. Regional air quality in Southeast Asia has been seasonally affected by the transboundary haze problem, which has often been the result of forest fires from "slash-and-burn" farming methods. In light of growing public health concerns, recent studies have begun to examine the health effects of this seasonal haze problem in Southeast Asia. This review paper aims to synthesize current research efforts on the impact of the Southeast Asian transboundary haze on acute aspects of public health. Existing studies conducted in countries affected by transboundary haze indicate consistent links between haze exposure and acute psychological, respiratory, cardiovascular, and neurological morbidity and mortality. Future prospective and longitudinal studies are warranted to quantify the long-term health effects of recurrent, but intermittent, exposure to high levels of seasonal haze. The mechanism, toxicology and pathophysiology by which these toxic particles contribute to disease and mortality should be further investigated. Epidemiological studies on the disease burden and socioeconomic cost of haze exposure would also be useful to guide policy-making and international strategy in minimizing the impact of seasonal haze in Southeast Asia.
\end{abstract}

Keywords: Big data; data analytics; transboundary; haze; air pollution; fire; healthcare; environmental epidemiology; public health

\section{Introduction}

Air pollution has emerged as one of the largest global environmental health threats in modern times [1]. Across countries, the focus of environmental disease burden has largely shifted from communicable diseases to noncommunicable diseases in adults [2], as medical technology and intervention capabilities continue to progress. This trend points towards an urgent necessity in investigating environment-associated noncommunicable diseases and deriving suitable mitigation measures, both in consideration of public health and the socioeconomic security of communities and nation states. Indeed, a large amount of research has demonstrated the deleterious health effects of 
exposure to air pollution in respiratory and cardiovascular illnesses, with the young and the elderly being the most vulnerable [3].

Similarly, air pollution has been an issue of paramount importance in Southeast Asia with Southeast Asian and Western Pacific regions bearing most of the burden [4]. Regional air quality in Southeast Asia has been seasonally affected by the transboundary haze problem in past decades, which has typically been the result of vegetation fires from "slash-and-burn" farming methods common in the area. These low-cost methods involve the burning of trees and plants in the farming fields to create a nutrient-rich ash layer largely devoid of weeds on which crops can be grown. This process releases large amounts of chemical and particulate airborne pollution. This has had immense economic, political, and health-related implications [5,6], and the near-catastrophic extent of the seasonal haze episodes has prompted concerted efforts to mitigate the situation. Most recently, the Association of Southeast Asian Nations (ASEAN) Agreement on Transboundary Haze Pollution has been ratified by all countries within ASEAN, pledging support to reduce haze pollution in Southeast Asia [7].

The regional nature of the problem has been the result of transboundary winds that transport the haze throughout more than half of the ASEAN countries, including Singapore, Indonesia, Malaysia, Brunei, Thailand, and the Philippines [8-10]. In addition, specific weather and climate conditions unique to the area, such as the dry weather conditions consequent of the El Nino-Southern Oscillation and positive Indian Ocean Dipole, have further worsened the severity of the haze engulfing the affected countries [11,12].

In general, the seasonal transboundary haze arises from combustion-associated smoke emissions, which comprise high concentrations of particulate matter fine enough to be carried airborne. A vast majority of the particles are less than 2.5 microns in size (PM2.5), and can therefore easily be suspended in wind currents for long periods of time, and are also sufficiently small to penetrate deep into the human respiratory tract $[13,14]$. In an acute setting, these seasonal haze episodes contribute to worsening asthma problems and other respiratory-related symptoms, but the long-term health risks of intermittent extreme episodes of seasonal haze exposure remains largely unclear. Some studies have suggested an increased risk of chronic diseases such as lung cancers, but these have been in the context of chronic exposure $[15,16]$. It has not been established if seasonal short-term, high-level repeated haze exposures confer similar increased cancer risks and other long-term health outcomes, as had been observed in North American or European urban settings that do not experience these extreme seasonal fluctuations in air pollution severity. A recent review by Reid et al. has also indicated a consistent demonstration of increased short-term respiratory morbidity and mortality consequent of seasonal smoke exposure from episodic wildfires [17], suggesting appropriate pertinence in comprehensively exploring the impact of the seasonal haze on acute health risks in Southeast Asia.

We recognize that the transboundary haze problem forms a growing public health concern. A multitude of recent studies have begun to examine the health effects of the Southeast Asian seasonal haze, in isolation and with regard to specific organ systems. The results of these research efforts help quantify the severity of the health burden of the annually recurring haze episodes, which in turn aids the formulation of regional and country-specific institutional policy responses. The purpose of this review paper is to close an important gap in the literature by synthesizing existing knowledge on the public health impact of the Southeast Asian transboundary haze. With a better understanding and a more extensive knowledge base, governments and organizations may be able to enact more effective response and resolution strategies in the near future.

\section{Findings and Results}

Our study involved a search of the following terms in PubMed, Google Scholar, and Cochrane Library: 'haze', 'transboundary haze', 'seasonal haze', 'South-east Asia', 'Asia', 'Pollutant Standards Index', 'air pollution', 'respiratory diseases', 'cardiovascular diseases', 'neurological diseases', 'psychological stress', 'psychosomatic symptoms', 'physical symptoms', and 'mortality'. We focused mainly on studies within the context of Southeast Asia; and some studies pertaining to Asia and 
elsewhere were used as reference point as and when required. We identified 44 articles for a full-text review after accounting for the duplicates and irrelevant articles, of which 31 directly address types of diseases and findings from haze-related health issues.

In the subsequent sections, we will give an overview of the health implications of the transboundary haze problem based on the results obtained from these studies. Figure 1 illustrates the decision process in our choice of papers undertaken in this review. Figure 2 and Table 1 provide a break-down of the selected papers.

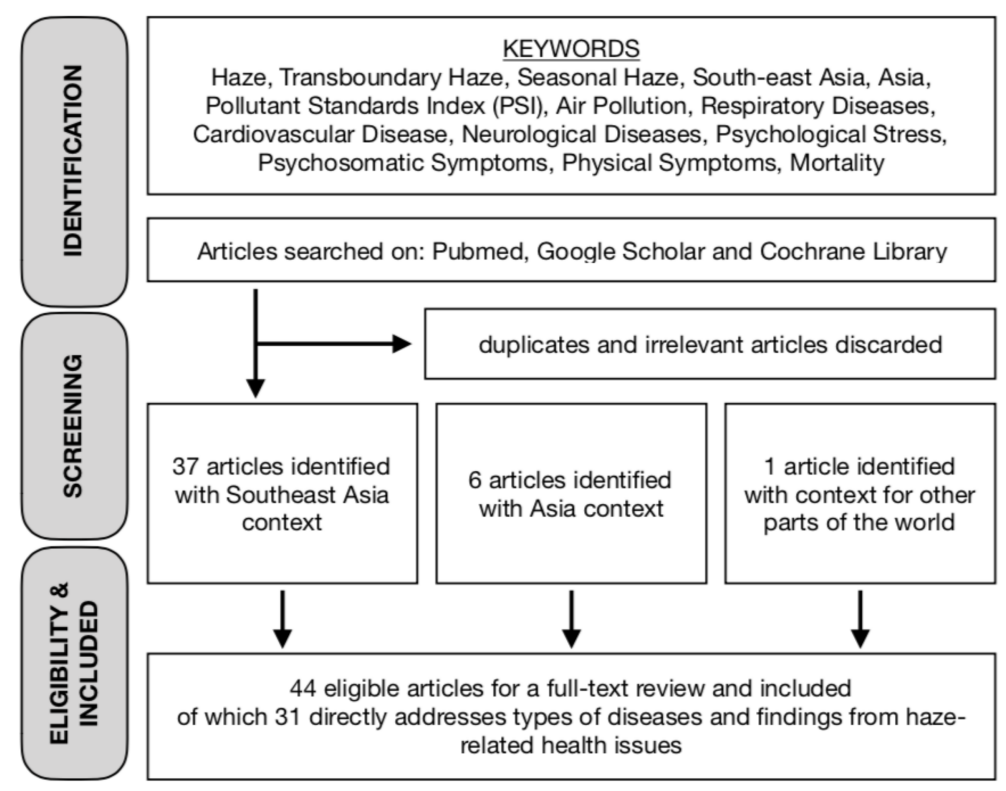

Figure 1. Flowchart of paper selection.

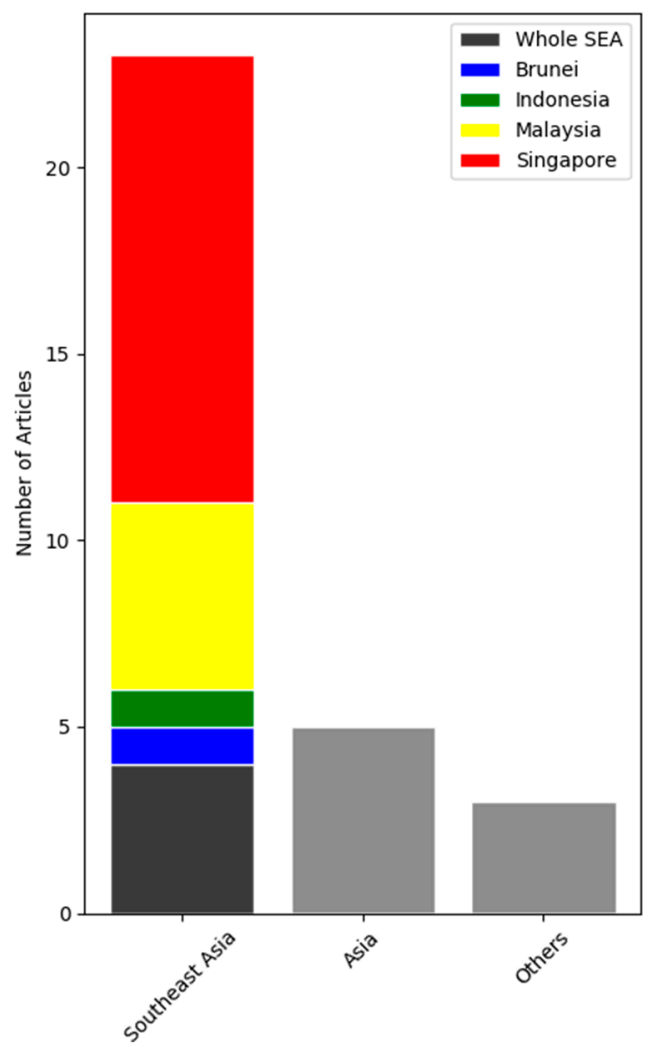

Figure 2. Number of articles relating to haze and health studies by region and country. 


\subsection{Physical Symptoms and Psychological Impact}

Small-scale retrospective studies have consistently demonstrated that a number of physical symptoms are exacerbated or worsened by the seasonal haze. These symptoms included sore throat or dry mouth, nose discomfort, eye discomfort, headache, shortness of breath, as well as skin irritation $[18,19]$. It was not always clear if these symptoms were exacerbations of underlying existing medical conditions (e.g., flare of endogenous eczema), or if the presence of new de novo symptoms brought on by the haze episodes.

A study from Singapore has also shown that the seasonal haze is associated with mild psychological stress [20]. This was examined by means of a cross-sectional, self-administered questionnaire. The total IES-R (Impacts of Events Scale-Revised) score in this study of 298 subjects was $18.47( \pm 11.69)$, which indicated that the study population experienced mild psychological stress, not amounting to acute stress reaction [20].

These psychosomatic symptoms experiences may have been in part mechanistically explained by alterations in cerebral hemodynamics as a result of exposure to haze. In a prospective study on healthy subjects with transcranial Doppler investigations conducted prior and after haze exposure, it had been found that there was a modest but significant decrease in pulsatility index (PI) and resistivity index (RI) in the left middle cerebral artery after haze exposure. Haze exposure resulted in significantly lower mean PI and RI in symptomatic subjects compared to baseline parameters, but was not significantly different in the asymptomatic subjects [21].

It would appear overall that there is concordance from prior studies demonstrating the effect of haze on the presence of psychological symptoms, which may have been mechanistically explained by acute changes in cerebral hemodynamics after haze exposure. A summary is found in Table 1.

\subsection{Respiratory Disease}

Respiratory symptoms and complaints predominate during a haze episode, although they tend to be mild. In Singapore, during the 1997 haze episode, an increase in PM10 levels from $50 \mathrm{microg} / \mathrm{m}^{3}$ to $150 \mathrm{microg} / \mathrm{m}^{3}$ was accompanied by a $12 \%$ increase in cases of upper respiratory tract illness, and $26 \%$ increase in cases of rhinitis [22]. Such symptoms are commonly presented to primary care providers, but it was more common to see cases of more serious lower respiratory conditions such as bronchitis and emphysema in periods of haze exposure [22]. It was also established that the persons at greater risk of these conditions are the very young and the elderly, as well as those living in urban environments and working outdoors [23]. Some studies have established a "dose-dependent" relationship between haze exposure and respiratory symptoms, where higher Pollutant Standards Index (PSI) values are associated with more frequent respiratory symptoms [9].

Notably, patients with preexisting respiratory conditions may be at risk of significant worsening in periods of seasonal haze. There have been increases in hospital admissions for exacerbations of chronic obstructive pulmonary disease during haze episodes, with elderly patients above 65 years of age being the most vulnerable [24]. Hospitalizations for asthma have also been shown to increase by as much as $20 \%$ in Singapore [25]. This may be attributed to the deterioration of pulmonary function as a direct effect of airborne particulate matter in the transboundary haze. A study on children have also indicated significant reduction in pulmonary function during haze episodes in comparison to pre-exposure conditions, especially in girls; when pulmonary function testing was repeated again after the haze episode, there was only partial recovery as residual effects from haze exposure remained [26]. This suggests possible long-term health implications from persistent residual effects, or at least a significant recovery period associated with each haze episode.

In general, haze exposure has consistently shown association with respiratory symptoms. Studies on respiratory symptoms have also been helpful in describing a dose-dependent relationship between the severity of haze and the presence of respiratory symptoms. 


\subsection{Neurological Diseases}

It has been established that long-term exposure to air pollution is associated with an increased risk of cerebrovascular disease [27]. Seasonal air quality deterioration in China, especially during cold winter months, when the pollution levels are $50 \%$ higher than baseline, has been previously associated with increased hospital admissions for stroke [28]. Beyond cerebrovascular diseases, other neurological conditions such as headaches and migraines are also more common after exposure to air pollution [28-30]. In Taiwan, studies have demonstrated that PM2.5 exposure in particular was independently associated with increased outpatient visits for headaches and migraines [31,32]. More recently, these trends have been demonstrated in Southeast Asia. A study from Singapore has demonstrated an association between haze exposure and an increased risk of stroke. Moderate and unhealthy levels of PSI correlated positively with stroke occurrence, with incidence risk ratios 1.10 (95\% confidence interval 1.06 to 1.13 ) and 1.14 (95\% confidence interval 1.03 to 1.25), respectively. This risk remained elevated 5 days after exposure [33].

The underlying pathophysiological mechanisms for haze exposure and neurological disease remain to be concretely elucidated. However, it has been postulated that some airborne particles in the transboundary haze may have vasoactive properties when inhaled, and may lead to alterations in cerebral hemodynamics [21]. It appeared that some subjects were more susceptible to these changes than others, and that alterations in the cerebral hemodynamics were correlated with the observed neurological symptoms, such as headaches. However, it is as yet unclear if the changes in cerebral hemodynamics can lead to an increased risk of stroke, or whether patients with existing cerebrovascular disease were more susceptible compared to healthy subjects.

Beyond respiratory diseases, haze exposure has also been associated with diseases of other organ systems. Although pathophysiological mechanisms and causality have not been robustly demonstrated, previous studies have consistently demonstrated the association of haze exposure with cerebrovascular disease and migraine.

\subsection{Cardiovascular Diseases}

Studies have postulated that mechanisms for cardiovascular disease after exposure to air pollution may be related to the direct toxicity of the inhaled particulate matter to the cardiovascular system or by indirect injury causing systemic inflammation, oxidative stress, and accelerated atherosclerosis [34,35]. An association between seasonal haze exposure and the occurrence of acute myocardial infarction has also been suggested by studies in Singapore [36,37]. It was found that the PSI was significantly associated with increased acute myocardial infarction occurrence, with each 30-unit increment in PSI being associated with IRR of 1.04 (95\% CI 1.03-1.06), as reflected in Table 2 [37].

Similar to neurological disease, previous authors have suggested pathophysiological mechanisms for the association between haze exposure and cardiovascular disease. However, although the mechanisms remain unclear, the association has been shown consistently.

\subsection{Mortality}

Out-of-hospital cardiac arrests have been shown to be more frequent during periods of seasonal haze exposure, when haze severity reach moderate and unhealthy PSI levels. In a 12 year time series analysis, it was demonstrated that a $10 \mu \mathrm{g} / \mathrm{m}^{3}$ increase in particulate matter was associated with significant increases in nonaccidental (PM10 ER: 0.627\%; 95\% confidence interval (CI): 0.260-0.995\% and PM2.5 ER: $0.660 \%$; 95\% CI: 0.204-1.118\%) and cardiovascular deaths (PM10 ER: 0.897; 95\% CI: $0.283-1.516$ and PM2.5 ER: $0.883 \%$; 95\% CI: 0.121-1.621\%) [38]. This study found that the impact of nonparticulate matter pollutants was minimal. Other studies on air pollution in other regions have similarly demonstrated increased cardiovascular mortality associated with higher levels of air pollution, with particular emphasis on PM2.5 exposure [39]. Similar trends had been observed in the 
seasonal haze episodes in Malaysia from 2000 to 2007, where higher mortality was observed with incrementally higher levels of PM10 exposure.

There was an observable lag or latency effect, in which the highest mortality was seen between 2 and 5 days after the exposure to haze [40]. The population at greatest risk was, again, the elderly, above 60 years of age, and children, under 14 years of age. In the elderly, the risk of cardiovascular death was up to twice as high after exposure to severe haze episodes [6].

Overall mortality has also been consistently shown to be high during periods of haze exposure. Of note, the extremes of age (elderly and young) have been the most vulnerable to this effect.

\section{Discussion}

The vast majority of studies investigating the acute health impact of seasonal haze in Southeast Asia has demonstrated an association between haze exposure and deleterious health effects, which range from physical and psychosomatic symptoms to respiratory, neurological, cardiovascular disease and mortality $[18,20,21,23-35,41,42]$. However, the evidence as a whole remains largely inconclusive for several reasons.

The first limitation of these studies is the availability of data. The ASEAN consist of many nations that currently lack robust air quality monitoring infrastructure to enable reliable data collection. The location of health events may be geographically distant from the nearest air pollution monitoring site. This may be partially dealt with using extrapolative modeling or satellite image plots but these have not been utilized in studies originating from this region. At the same time, in certain nations there is additionally the reluctance of government agencies to release pollutant data for research.

Secondly, some of the larger studies from the region suffer from using an air quality index as the exposure of interest. For example, in Singapore, PSI has been shown to correlate with acute myocardial infarction, out-of-hospital cardiac arrest, and acute ischemic stroke $[33,37,38]$. While PSI is useful as a public communication tool due to its ability to summarize the state of pollution into a single number which the public can easily interpret, in comparative research it becomes ineffective. Also, the study of threshold effects is compromised due to its nonlinear scale.

Thirdly, the studies which are predominantly of time series or case crossover designs, suffer from fundamental limitations of ecological studies. In addition, the small size and retrospective nature of most studies limit their usefulness. These designs also make it difficult to isolate the effect of transboundary haze from endogenous sources of pollutants such as industrial and vehicular sources. A future direction would be to study some of the high-quality cohort studies currently housed within the region.

Lastly, a major limitation has been the difficulty in quantifying the true exposure of individuals to the transboundary haze. Furthermore, differences in socioeconomic status and working exposure (i.e., outdoor work versus indoor air-conditioned environment) may also influence the degree of true exposure to the environmental haze. The subjective health beliefs of individuals, in the form of the perceived threat that the haze poses, may also have influenced the duration of time spent outdoors, or the enactment of protective measures, such as the usage of masks or air filters. These differences are difficult to quantify, and most studies did not fully explore if individuals with differing exposure levels present different health implications.

Most of the data on seasonal haze originates from the countries of Singapore, Malaysia, and Brunei. There is a paucity of data from the most affected countries such as Indonesia, Thailand and Philippines. Data from these severely affected countries would be valuable in adding to the comprehensive understanding of the epidemiology and disease associations in the region.

Reassuringly, many studies on health outcomes had spanned a number of years. The trends of increased stroke and cardiovascular mortality had not just been demonstrated in an isolated haze season, but consistently demonstrated yearly with each seasonal haze exposure [28,29,31]. The studies had also consistently demonstrated that young children and the elderly were at the highest risk of health effects after exposure to haze [24,25], which may be related to a poorer or impaired immune 
system, as well as the potential presence of preexisting health conditions that may have been easily exacerbated by the environmental haze exposure.

We also note that there has been a shift in research effort towards examining the mechanism, toxicology and pathophysiology in which exposure to haze contributes to disease. A study from Singapore has demonstrated changes in cerebral hemodynamics after haze exposure and its association with the presence of psychosomatic symptoms [21]. However, the subjects studied were all young and healthy volunteers, and it is unclear if differential effects were present in those with preexisting cerebrovascular disease. Longitudinal studies were also lacking to evaluate if long-term health outcomes were affected by these differences in cerebral hemodynamics.

Studies on a cellular level have shown that human epithelial cell lines had decreased cell viability and increased cell death when exposed to PM2.5 samples collected during a severe haze episode. There were low levels of glutathione and caspase-3/7 in the cells affected, which may have led to higher levels of reactive oxygen species that cause oxidative stress and eventual cell death. These effects were attributed to metal-bound particulate matter and polycyclic aromatic hydrocarbons in the haze, and, given this mechanism, may contribute to inflammation in the airways and lungs, and consequently respiratory symptoms with recurrent haze exposure [13]. More studies evaluating the measurement of particulate matter in humans such as from blood or urine samples, or via other biomarkers may be useful to improve further understanding and quantify the toxic effects of haze exposure.

While greater awareness of seasonal haze and its health effects has led to growing academic interest, there still remains a scarcity of data on the effects of seasonal haze and its burden on primary care providers. Minor ailments that require attention may be seen in various contexts by general practitioners, or in some cases, emergency department visits. Collating data on the increase in volume of cases experienced by primary care providers or emergency departments during haze exposure would help to guide important health policies.

\section{Conclusions and Outlook}

The seasonal transboundary haze problem in Southeast Asia has become recurrent and is of significant public health concern. Although there has been a paucity of data from several low-middle-income countries, existing studies arising from some of the affected countries suggest consistent deleterious effects on psychological, respiratory cardiovascular, neurological morbidity, and mortality; and this motivates future work.

Addressing the limitations of the current literature in this area, research in this field may be enhanced in several ways. First is to improve the quality of the exposure data. This may mean government investment into developing air quality monitoring infrastructure. In other countries which already possess this, it then becomes necessary to navigate the bureaucratic barriers to data availability.

Secondly, future studies should move beyond describing disease association, to quantify impact on health service utilization as this allows another dimension of the quantification of the economic cost of transboundary haze episodes and also facilitates in the planning of healthcare resources. These would involve events such as ambulance callouts, emergency department visits, and hospital admissions. Having such data will then allow the evaluation of public health interventions such as mask distribution exercises or school closure policies.

Future prospective and longitudinal studies are warranted to quantify the long-term health effects of recurrent but intermittent exposure to high levels of seasonal haze. These studies should look into the mechanism, toxicology and pathophysiology by which these toxic particles contribute to disease and mortality. In-depth study of retroactive measures to provide healthcare to those afflicted by haze related illnesses, as well as to study the severity of health effects due to seasonal haze, can prepare the healthcare sector and authorities in anticipation for seasonal haze. While taking retrospective action may decrease the number of those who suffer from long-term health affliction, being active in predicting seasonal haze and its severity should be at the forefront so that action can be taken as a preventive measure. 
With the continued progress of technology, it is also hoped that artificial intelligence-based approaches can be used to forecast PM2.5 during haze episodes [43,44]. In India, an advanced machine learning technique was used to effectively forecast haze episodes over urbanized areas. The approach employed the combined use of neural networks and fuzzy logic for predicting PM2.5 levels during haze conditions. These novel techniques were compared against conventional methods; it was convincingly shown that artificial intelligence techniques had significantly better agreement with the observed values, especially in the context of urbanized districts like Delhi [43].

We also emphasize that epidemiology studies on the disease burden and socioeconomic cost of haze exposure would be useful to guide policy and strategy in minimizing the health impact of the seasonal haze in Southeast Asia. However, preventive and retrospective action will not solve the issues or eliminate the source of the haze. Therefore, we conclude this review paper by encouraging farmers to adopt more sustainable practices with effective fire and forest management to "tackle the haze issue at its root." The slash-and-burn agricultural practice may be economical for landowners, but it has a great socioeconomic burden on a larger scale. Whenever possible, related authorities should aid greatly in incentivizing the shift towards alternatives, especially when considering cost balance to be the primary impetus in the widespread use of slash-and-burn techniques in the first place. 
Table 1. Key findings of haze-related health issues.

\begin{tabular}{|c|c|c|}
\hline Article & $\begin{array}{c}\text { Region/Study } \\
\text { country/Period of Study }\end{array}$ & Key Findings \\
\hline $\begin{array}{l}\text { Chew, et al. } \\
\text { (1995) [25] }\end{array}$ & $\begin{array}{l}\text { SEA/Singapore/September to } \\
\text { October } 1994\end{array}$ & $\begin{array}{l}\text { - An increase in emergency room attendances for acute childhood asthma in two large general hospitals } \\
\text { in Singapore }\end{array}$ \\
\hline $\begin{array}{l}\text { Hashim, et al. } \\
\text { (1998) [26] }\end{array}$ & $\begin{array}{l}\text { SEA/Malaysia/July to } \\
\text { November } 1997\end{array}$ & $\begin{array}{l}\text { - Significant reductions (mean } 18 \% \text { ) in pulmonary function among children during and after the episode } \\
\text { when compared to the pre-episode period. } \\
\text { The mean reduction in percentage predicted FEV1 and FVC and ratio FEV1/FVC during the haze were } \\
\text { lower among the girls }(21,19 \text {, and } 8 \% \text { respectively) than among the boys }(16,10 \text {, and } 5 \% \text { respectively). }\end{array}$ \\
\hline $\begin{array}{l}\text { Tan, et al. } \\
(2000)[19]\end{array}$ & $\begin{array}{l}\text { SEA/Singapore/29 September } \\
\text { to } 27 \text { October } 1997 \text { and } 21 \\
\text { November to } 5 \text { December } \\
1997\end{array}$ & $\begin{array}{l}\text { - The study examined the association between acute air pollution caused by biomass burning and } \\
\text { peripheral white blood cell counts in humans. } \\
\text { Serial measurements of the WBC count made during the } 1997 \text { Southeast Asian Smoke-haze (Sep } 29 \text { to } \\
\text { Oct 27) were compared with a period after the haze cleared (Nov } 21 \text { to Dec 5) using peripheral blood } \\
\text { polymorphonuclear leukocytes (PMN) band cells to monitor marrow release. } \\
\text { Atmospheric pollution caused by biomass burning is associated with elevated circulating band cell } \\
\text { counts in humans because of the increased release of PMN precursors from the marrow-this response } \\
\text { may contribute to the pathogenesis of cardiorespiratory morbidity associated with acute air pollution. }\end{array}$ \\
\hline $\begin{array}{l}\text { Odihi } \\
(2001)[9]\end{array}$ & $\begin{array}{l}\text { SEA/Brunei/September } 1997 \\
\quad \text { to September } 1998\end{array}$ & $\begin{array}{l}\text { - The deleterious effects of haze appeared skewed towards the young (age: } 1-5 \text { years) and the aged ( } \geq 60 \\
\text { years). A higher proportion of urban population was more adversely affected than in rural areas and, } \\
\text { other things being equal, a higher proportion of outdoor workers were more adversely affected by } \\
\text { haze than their indoor counterparts. } \\
\text { - Conjunctivitis related cases did not have any significant increase during the exposure period. }\end{array}$ \\
\hline $\begin{array}{l}\text { Sastry } \\
(2002)[6]\end{array}$ & $\begin{array}{l}\text { SEA/Malaysia/April to } \\
\text { November } 1997\end{array}$ & $\begin{array}{l}\text { - Total mortality associated with a } 100 \mathrm{\mu g} / \mathrm{m}^{3} \text { increase in } \mathrm{PM}_{10} \text { concentrations for Kuala Lumpur, } \\
\text { associated relative risk is } 1.07 \text {. } \\
\text { For one segment of the Malaysian population-those aged } 65 \text { to } 74 \text { in Kuala Lumpur-there was an } \\
\text { upward shift in mortality that lasted at least a few weeks. }\end{array}$ \\
\hline
\end{tabular}


Table 1. Cont.

\begin{tabular}{|c|c|c|}
\hline Article & $\begin{array}{c}\text { Region/Study } \\
\text { country/Period of Study }\end{array}$ & Key Findings \\
\hline $\begin{array}{l}\text { Frankenberg, et al. } \\
\text { (2005) [23] }\end{array}$ & SEA/Indonesia/1993 and 1997 & $\begin{array}{l}\text { - Comparisons of the health of the population living in haze areas with the health of those in other areas } \\
\text { substantially overestimated the "effect" of the fires because of time-varying location-specific } \\
\text { unobserved heterogeneity in health status. } \\
\text { One in } 3 \text { adult respondents over the age of thirty reported coughing as the major health issue during } \\
\text { the } 1997 \text { haze episode. }\end{array}$ \\
\hline $\begin{array}{l}\text { Mott, et al. } \\
\text { (2005) [24] }\end{array}$ & $\begin{array}{l}\text { SEA/Malaysia (Kuching)/ } \\
\text { January } 1995 \text { to December } \\
1998\end{array}$ & $\begin{array}{l}\text { - Comparisons of long-term cardiorespiratory disease classifications were done. } \\
\text { - Significant increases in respiratory hospitalizations, particularly those due to asthma, were observed in } \\
\text { the } 19-39 \text { - and } 40-64 \text {-year-old categories. } \\
\text { Persons over age } 65 \text { with prior hospitalizations for respiratory diseases were significantly more likely } \\
\text { than others to be rehospitalized for their conditions during the forest fire. }\end{array}$ \\
\hline $\begin{array}{l}\text { Szyszkowicz, et al. } \\
\text { (2009) [29] }\end{array}$ & $\begin{array}{c}\text { Others/Canada } \\
\text { (Edmonton)/1992 to } 2002\end{array}$ & $\begin{array}{l}\text { - Findings provide preliminary evidence of an association between air pollution and emergency } \\
\text { department visits for migraine and nonspecific headache. Findings were most consistent for } \\
\text { particulate matter. }\end{array}$ \\
\hline $\begin{array}{l}\text { Szyszkowicz, et al. } \\
\text { (2009) [30] }\end{array}$ & $\begin{array}{l}\text { Others/Canada (Edmonton, } \\
\text { Hali- fax, Ottawa, Toronto, } \\
\text { and Vancouver)/data from } \\
11518 \text { days for five cities. }\end{array}$ & $\begin{array}{l}\text { - For female ED visits for migraine, positive associations were observed during the warm season for } \\
\text { sulfur dioxide }\left(\mathrm{SO}_{2}\right) \text {, and in the cold season for particulate matter }\left(\mathrm{PM}_{2.5}\right) \text { exposures lagged by 2-days. } \\
\text { The percentage increase in daily visits was } 4.0 \%(95 \% \mathrm{CI}: 0.8-7.3) \text { for } \mathrm{SO}_{2} \text { mean level change of } 4.6 \mathrm{ppb} \text {, } \\
\text { and } 4.6 \%(95 \% \mathrm{CI}: 1.2-8.1) \text { for } \mathrm{PM}_{2.5} \text { mean level change of } 8.3 \mu \mathrm{g} / \mathrm{m}^{3} \text {. For male ED visits for headache, } \\
\text { the largest association was obtained during the warm season for nitrogen dioxide }\left(\mathrm{NO}_{2}\right) \text {, which was } \\
13.5 \% \text { (95\% CI: 6.7-20.7) for same day exposure. }\end{array}$ \\
\hline $\begin{array}{l}\text { Yang, et al. } \\
\text { (2012) [39] }\end{array}$ & $\begin{array}{c}\text { Asia/China } \\
\text { (Guangzhou)/2007 to } 2008\end{array}$ & $\begin{array}{l}\text { - The averaged } \mathrm{PM}_{2.5} \text { concentration in } 2007-2008 \text { was } 70.1 \mu \mathrm{g} / \mathrm{m}^{3} \text { in Guangzhou, which was } \\
\text { approximately seven times higher than the WHO Air Quality Guidelines. } \\
\text { An increase of } 10 \mu \mathrm{g} / \mathrm{m}^{3} \text { in 2-day moving average (lag01) concentration of } \mathrm{PM}_{2.5} \text { corresponds to } 0.90 \% \\
\text { [ } 95 \% \text { confidence interval (CI): } 0.55,1.26 \% \text { ] increase of total mortality, } 1.22 \%(95 \% \text { CI: } 0.63,1.68 \% \text { ) } \\
\text { increase of cardiovascular mortality, and } 0.97 \% \text { ( } 95 \% \text { CI: } 0.16,1.79 \% \text { ) increase of respiratory mortality. } \\
\text { - The associations were stronger in the elderly (aged } 65 \text { years or more), in females, and in those with low } \\
\text { education level, but the differences were statistically insignificant. }\end{array}$ \\
\hline $\begin{array}{l}\text { Andersen, et al. } \\
\text { (2012) [27] }\end{array}$ & $\begin{array}{l}\text { Others/Denmark } \\
\text { (Copenhagen and } \\
\text { Aarhus)/data from } 1971 \text { to } \\
2006\end{array}$ & $\begin{array}{l}\text { Over a mean follow-up of } 9.8 \text { years of } 52215 \text { eligible subjects, there were } 1984 \text { (3.8\%) first-ever } \\
\text { (incident) hospital admissions for stroke of whom } 142(7.2 \%) \text { died within } 30 \text { days. Detected borderline } \\
\text { significant associations between mean nitrogen dioxide levels at residence since } 1971 \text { and incident } \\
\text { stroke (hazard ratio, } 1.05 ; 95 \% \text { CI, } 0.99-1.11 \text {, per interquartile range increase) and stroke hospitalization } \\
\text { followed by death within } 30 \text { days }(1.22 ; 1.00-1.50) \text {. } \\
\text { The associations were strongest for nonspecified and ischemic strokes, whereas no association was } \\
\text { detected with hemorrhagic stroke. }\end{array}$ \\
\hline
\end{tabular}


Table 1. Cont

\begin{tabular}{|c|c|c|}
\hline Article & $\begin{array}{c}\text { Region/Study } \\
\text { country/Period of Study }\end{array}$ & Key Findings \\
\hline $\begin{array}{l}\text { Abba, et al. } \\
(2012)[16]\end{array}$ & $\begin{array}{l}\text { Asia/India (Mumbai) /2007 to } \\
2008\end{array}$ & $\begin{array}{l}\text { - The average outdoor } \mathrm{PM}_{2.5} \text { mass concentrations at control, kerb, residential and industrial sites were } \\
69+21,84+32,89+34,95+36 \mu \mathrm{g} / \mathrm{m}^{3} \text {. } \\
\text { - The sums of PAHs in } \mathrm{PM}_{2.5} \text { at same above four sites were } 35.27+2.10,42.96+2.49,175.76+8.95 \text { and } \\
90.78+4.74 \mu \mathrm{g} / \mathrm{m}^{3} \text {, respectively. } \\
\text { Estimating the carcinogenic potential of PAHs with equivalents of Benzo(a)pyrene (BaPE). The } \\
\text { maximum value of BaPE (18.8) was reported in the residential site. }\end{array}$ \\
\hline $\begin{array}{l}\text { Xiang, et al. } \\
\text { (2013) [28] }\end{array}$ & $\begin{array}{l}\text { Asia/China (Wuhan)/2006 to } \\
2008\end{array}$ & $\begin{array}{l}\text { - Time stratified case crossover design by season (April-September and October-March) was performed } \\
\text { to assess effects of pollutant on stroke hospital admissions. } \\
\text { Exposure to } \mathrm{NO}_{2} \text { is significantly associated with stroke hospitalizations during the cold season in } \\
\text { Wuhan, China when pollution levels are } 50 \% \text { greater than in the warm season. }\end{array}$ \\
\hline $\begin{array}{l}\text { Marlier, et al. } \\
\text { (2013) [8] }\end{array}$ & SEA/All/1997 to 2006 & $\begin{array}{l}\text { During strong El Niño years, fires contribute up to } 200 \mu \mathrm{g} / \mathrm{m}^{3} \text { and } 50 \mathrm{ppb} \text { in annual average fine } \\
\text { particulate matter }\left(\mathrm{PM}_{2.5}\right) \text { and ozone }\left(\mathrm{O}_{3}\right) \text { surface concentrations near fire sources, respectively. } \\
\text { Corresponds to a fire contribution of } 200 \text { additional days per year that exceed the World Health } \\
\text { Organization (WHO) } 50 \mu \mathrm{g} / \mathrm{m}^{3} \text { 24-hour } \mathrm{PM}_{2.5} \text { interim target (IT-2) and an estimated } 10,800 \\
(6800-14,300) \text { person }(\sim 2 \%) \text { annual increase in regional adult cardiovascular mortality. }\end{array}$ \\
\hline $\begin{array}{l}\text { Betha, et al. } \\
(2014)[5]\end{array}$ & $\begin{array}{l}\text { Southeast Asia (SEA)/All/June } \\
2013\end{array}$ & $\begin{array}{l}\left.\text { - } \mathrm{PM}_{2.5} \text { concentrations were elevated (up to } 329 \mu \mathrm{g} / \mathrm{m}^{3}\right) \text { during the haze episode, compared to those } \\
\text { during the non-haze period }\left(11-21 \mu \mathrm{g} / \mathrm{m}^{3}\right) \text {. } \\
\text { - There was a } 10 \text {-fold increase in the concentration of } \mathrm{K} \text {, an inorganic tracer of biomass burning. } \\
\text { - Health risk estimates revealed that the excessive lifetime carcinogenic risk to individuals exposed to } \\
\text { biomass burning-impacted aerosols }\left(18 \pm 1 \times 10^{-6}\right) \text { increased significantly }(p<0.05) \text { compared to those } \\
\text { who exposed to urban air }\left(12 \pm 2 \times 10^{-6}\right) \text {. }\end{array}$ \\
\hline
\end{tabular}


Table 1. Cont

\begin{tabular}{|c|c|c|}
\hline Article & $\begin{array}{c}\text { Region/Study } \\
\text { country/Period of Study }\end{array}$ & Key Findings \\
\hline $\begin{array}{l}\text { Sahani, et al. } \\
\text { (2014) [40] }\end{array}$ & $\begin{array}{c}\text { SEA/Malaysia (Klang } \\
\text { Valley)/data from } 2000 \text { to } 2007\end{array}$ & $\begin{array}{l}\text { - A total of } 88 \text { haze days were identified in the Klang Valley region during the study period. A total of } \\
126,822 \text { cases of death were recorded for natural mortality where respiratory mortality represented } \\
8.56 \%(N=10,854) \text {. } \\
\text { - Haze events were found to be significantly associated with natural and respiratory mortality at various } \\
\text { lags. For natural mortality, haze events at lagged } 2 \text { showed significant association with children less } \\
\text { than } 14 \text { years old (Odd Ratio }(\mathrm{OR})=1.41 ; 95 \% \text { Confidence Interval }(\mathrm{CI})=1.01-1.99) \text {. } \\
\text { Respiratory mortality was significantly associated with haze events for all ages at lagged } 0(\mathrm{OR}=1.19 \text {; } \\
95 \% \mathrm{CI}=1.02-1.40) \text {. }\end{array}$ \\
\hline $\begin{array}{l}\text { Yeo, et al. } \\
\text { (2014) [18] }\end{array}$ & $\begin{array}{c}\text { SEA/Singapore/25 June to } 11 \\
\text { July } 2013\end{array}$ & $\begin{array}{l}\text { - Seventy-two consultations were conducted over the 3-week period, of which } 26(36.1 \%) \text { were haze } \\
\text { related, } 18(25 \%) \text { were possibly haze related and } 28(38.9 \%) \text { were non-haze related. } \\
\text { - The majority of haze-related complaints were respiratory, eye and skin- related. }\end{array}$ \\
\hline $\begin{array}{l}\text { Ho, et al. } \\
\text { (2014) [20] }\end{array}$ & $\begin{array}{l}\text { SEA/Singapore/21 June to } 26 \\
\text { June } 2013\end{array}$ & $\begin{array}{l}\text { - Study was conducted between June } 21 \text { and June 26, 2013. Participants were recruited by online } \\
\text { recruitment post. Participants were required to complete an online survey which was composed of } \\
\text { demographics questionnaire, physical symptom checklist, perceived dangerous Pollutant Standard } \\
\text { Index (PSI) value, and views on the N-95 mask and the Impact of Event Scale-Revised (IES-R). } \\
\text { A total of } 298 \text { participants returned the completed study questionnaire. The respondents reported a } \\
\text { mean number of } 4.03 \text { physical symptoms (S.D. = 2.6). The five most common physical symptoms } \\
\text { include mouth or throat discomfort }(68.8 \%) \text {, nose discomfort }(64.1 \%) \text {, eye discomfort }(60.7 \%) \text {, headache } \\
\text { (50.3\%), and breathing difficulty }(40.3 \%) \text {. } \\
\text { The total IES-R score was } 18.47 \text { (S.D. }=11.69) \text { which indicated that the study population experienced } \\
\text { mild psychological stress but not to the extent of acute stress reaction syndrome. }\end{array}$ \\
\hline $\begin{array}{l}\text { Reddington, et al. } \\
\text { (2014) [10] }\end{array}$ & $\begin{array}{l}\text { SEA/ Indonesia, Malaysia and } \\
\text { Singapore/2004 to } 2009\end{array}$ & $\begin{array}{l}\text { - Fires in southern Sumatra account for the greatest percentage of the total fire enhancement to } \mathrm{PM}_{2.5} \\
\text { concentrations in Singapore }(42-62 \%) \text {, with fires in central Sumatra and Kalimantan contributing } \\
21-35 \% \text { and } 14-15 \% \text {, respectively. } \\
\text { Explored the impact of vegetation and peat fires on } \mathrm{PM}_{2.5} \text { concentrations across other major cities in } \\
\text { the region. Fires that contributed most to } \mathrm{PM}_{2.5} \text { concentrations in Singapore also contributed } \\
\text { substantially to the concentrations across the rest of the region. Jakarta, Palembang and Batam are } \\
\text { mostly impacted by the fires in southern Sumatra (accounting for } 51-74 \% \text { of the total fire enhancement } \\
\text { to } \mathrm{PM}_{2.5} \text { ), whereas Kuala Lumpur and Pekanbaru are impacted most by fires in central Sumatra } \\
\text { (accounting for } 69-74 \% \text { of the total fire enhancement to PM } \mathrm{PM}_{2.5} \text { ). } \\
\text { Targeting fire reduction efforts to improve air quality in Singapore will also improve air quality in } \\
\text { other major cities in Indonesia and Malaysia. }\end{array}$ \\
\hline
\end{tabular}


Table 1. Cont.

\begin{tabular}{|c|c|c|}
\hline $\begin{array}{l}\text { Chen, et al. } \\
\text { (2015) [31] }\end{array}$ & $\begin{array}{l}\text { Asia/Taiwan (Taipei)/data } \\
\text { from } 2006 \text { to } 2011\end{array}$ & $\begin{array}{l}\text { - No significant associations between } \mathrm{PM}_{2.5} \text { levels and migraine visits were observed on cool days. } \\
\text { - On warm days, for the single pollutant model, there is a } 13 \% \text { increased clinic visits for migraine were } \\
\text { significantly associated with } \mathrm{PM}_{2.5} \text { levels. }\end{array}$ \\
\hline $\begin{array}{l}\text { Chang, et al. } \\
\text { (2015) [32] }\end{array}$ & $\begin{array}{l}\text { Asia/Taiwan (Taipei)/data } \\
\text { from } 2006 \text { to } 2011\end{array}$ & $\begin{array}{l}\text { - Increased outpatient department (OPD) visits for headaches were significantly associated with levels } \\
\text { of } \mathrm{PM}_{2.5} \text { both on warm days }\left(>23^{\circ} \mathrm{C}\right) \text { and cool days }\left(<23^{\circ} \mathrm{C}\right) \text {, with an interquartile range rise } \\
\text { associated with a } 12 \%(95 \% \mathrm{CI}=10-14 \%) \text { and } 3 \%(95 \% \mathrm{CI}=1-5 \%) \text { elevation in OPD visits for } \\
\text { headaches, respectively. }\end{array}$ \\
\hline $\begin{array}{l}\text { Koplitz, et al. } \\
\text { (2016) [12] }\end{array}$ & $\begin{array}{l}\text { SEA/ Indonesia, Malaysia and } \\
\text { Singapore/September to } \\
\text { October } 2015 \text { compared to } \\
\text { haze of September to October } \\
2006\end{array}$ & $\begin{array}{l}\text { - Using the adjoint of the GEOS-Chem chemical transport model, they calculated the influence of } \\
\text { potential fire emissions across the domain on smoke concentrations in three receptor areas - Indonesia, } \\
\text { Malaysia and Singapore during the haze episode of } 2006 \text {. } \\
\text { The model framework introduced in this study identified areas where land use management to reduce } \\
\text { and/or avoid fires would yield the greatest benefit to human health, both nationally and regionally. }\end{array}$ \\
\hline $\begin{array}{l}\text { Khan, et al. } \\
(2016)[15]\end{array}$ & $\begin{array}{l}\text { SEA/Malaysia/July to } \\
\text { September } 2013 \text { and January } \\
\text { to February } 2014\end{array}$ & $\begin{array}{l}\text { - Samples are collected from a building } 65 \mathrm{~m} \text { above sea level, } 1 \mathrm{~km} \text { from the main highway road. } \\
\text { - The hazard quotient for four selected metals }(\mathrm{Pb}, \mathrm{As}, \mathrm{Cd} \text {, and } \mathrm{Ni}) \text { in } \mathrm{PM}_{2.5} \text { mass was highest in } \mathrm{PM}_{2.5} \\
\text { mass from the coal burning source and least in } \mathrm{PM}_{2.5} \text { mass originating from the mineral/road } \\
\text { dust source. } \\
\text { - The main carcinogenic heavy metal of concern to health at the location was As. Overall, the associated } \\
\text { lifetime cancer risk posed by the exposure of hazardous metals in } \mathrm{PM}_{2.5} \text { is } 3-4 \text { per 1,000,000 people at } \\
\text { the location. }\end{array}$ \\
\hline $\begin{array}{l}\text { Ho, et al. } \\
(2018)[33]\end{array}$ & $\begin{array}{l}\text { SEA/Singapore/data from } \\
2010 \text { to } 2015\end{array}$ & $\begin{array}{l}\text { - There were } 29,384 \text { ischemic stroke cases. Moderate and unhealthy Pollutant Standards Index levels } \\
\text { showed association with stroke occurrence, with incidence risk ratio } 1.10 \text { ( } 95 \% \text { confidence interval } 1.06 \\
\text { to } 1.13) \text { and } 1.14 \text { ( } 95 \% \text { confidence interval } 1.03 \text { to } 1.25) \text {, respectively. } \\
\text { The association was significant in subgroups aged } 65 \text { years or older, women, Chinese, nonsmokers and } \\
\text { those with history of diabetes, hypertension, and hyperlipidemia. }\end{array}$ \\
\hline $\begin{array}{l}\text { Yap, et al. } \\
\text { (2019) [38] }\end{array}$ & $\begin{array}{l}\text { SEA/Singapore/data from } \\
2010 \text { to } 2015\end{array}$ & $\begin{array}{l}\text { - Study found that } 10 \mu \mathrm{g} / \mathrm{m} 3 \text { increase in particulate matter was associated with increases in } \\
\text { nonaccidental (PM10 ER: 0.627\%; 95\% confidence interval (CI): } 0.260-0.995 \% \text { and PM2.5 ER: 0.660\%; } \\
\text { 95\% CI: 0.204-1.118\%) and cardiovascular mortality (PM10 ER: 0.897; } 95 \% \text { CI: } 0.283-1.516 \text { and PM2.5 } \\
\text { ER: } 0.883 \% \text {; } 95 \% \text { CI: 0.121-1.621\%). Acute effects were significant in the elderly (aged } 65 \text { and above) } \\
\text { but not in non-elderly. } \\
\text { Effects by other pollutants were minimal. }\end{array}$ \\
\hline
\end{tabular}


Table 1. Cont.

\begin{tabular}{|c|c|c|}
\hline $\begin{array}{l}\text { Ho, et al. } \\
\text { (2018) [42] }\end{array}$ & $\begin{array}{l}\text { SEA/Singapore/data from } \\
2010 \text { to } 2015\end{array}$ & $\begin{array}{l}\text { - There were } 105,504 \text { deaths during the study period. Moderate (Risk ratio/IRR }=1.05 ; 95 \% \mathrm{CI}= \\
1.03-1.07) \text { and unhealthy (Risk Ratio/IRR }=1.08 ; 95 \% \mathrm{CI}=1.03-1.14) \mathrm{PSI} \text { levels show significant } \\
\text { association with all-cause mortality. Unhealthy temperatures (above } 28.5{ }^{\circ} \mathrm{C} \text { ) also show significant } \\
\text { association at a Risk Ratio/IRR }=1.04 ; 95 \% \mathrm{CI}=1.02-1.06 \text {. } \\
\text { Each increment of } 30 \text { units in PSI on the same day and previous } 1-5 \text { days was significantly associated } \\
\text { with } 2.51-3.40 \% \text { excess risk of mortality }(p<0.001) \text {. Each increment of } 1{ }^{\circ} \mathrm{C} \text { in temperature exhibited } \\
\text { health implications in lag day } 0-2 \text { with } 0.95 \%-2.00 \% \text { excess risk of mortality }(p<0.05) .\end{array}$ \\
\hline $\begin{array}{l}\text { Tan, et al. } \\
(2019) \text { [21] }\end{array}$ & SEA/Singapore/2015 & $\begin{array}{l}\text { - Study participants' median age was } 30 \text { years (IQR } 26-34) \text {, and new psychosomatic symptoms were } \\
\text { reported by } 35(47.3 \%) \text {. There was a modest but significant decrease in pulsatility index (PI) and } \\
\text { resistivity index (RI) in the left MCA after haze exposure (PI: } p=0.026 ; \text { RI: } p=0.021) \text {. } \\
\text { Haze causes significant alterations in cerebral hemodynamics in susceptible individuals, probably } \\
\text { responsible for various psychosomatic symptoms. }\end{array}$ \\
\hline $\begin{array}{l}\text { Ho, et al. } \\
\text { (2019) [37] }\end{array}$ & $\begin{array}{l}\text { SEA/Singapore/data from } \\
2010 \text { to } 2015\end{array}$ & $\begin{array}{l}\text { - Investigated association between air pollution and acute myocardial infarction (AMI) incidence } \\
\text { in Singapore. } \\
\text { Each 30-unit increase in PSI showed significant association with increased AMI occurrence with } \\
\text { incidence risk ratio (IRR) of } 1.04 \text { and } 95 \% \text { confidence interval }(95 \% \mathrm{CI} \text { ) of } 1.03-1.06 \text {. In the subgroup of } \\
\text { ST-segment elevation myocardial infarction (STEMI), the IRR was } 1.00 \text { and } 95 \% \text { CI was } 0.98-1.03 \text {; while } \\
\text { among NSTEMI, the IRR was 1.08, and 95\%CI was } 1.05-1.10 \text {. } \\
\text { Moderate and unhealthy PSI showed association with AMI occurrence with IRR } 1.0895 \% \text { CI } 1.05-1.11 \\
\text { and IRR 1.09 95\%CI 1.01-1.18, respectively. Excess risk remained elevated through the day of exposure } \\
\text { and for up to five day after exposure (>2 years for Ho et al.). }\end{array}$ \\
\hline
\end{tabular}


Table 2. Estimated incidence rate ratio of myocardial infarction for each 30-unit increment in pollutant standards index for the entire study cohort and by subgroups of demographic and clinical characteristics ( $n=2191$ Days). Table reproduced with explicit permission from the authors of [37].

\begin{tabular}{|c|c|c|}
\hline Groups & Incidence Rate Ratio (95\% CI) & $p$-Value \\
\hline Entire cohort & $1.04(1.03-1.06)$ & 0.001 \\
\hline Without overdispersion and autocorrelation & $1.04(1.03-1.06)$ & 0.001 \\
\hline \multicolumn{3}{|c|}{ Subgroups } \\
\hline \multicolumn{3}{|c|}{ Age } \\
\hline $65 y$ & $1.04(1.02-1.07)$ & 0.001 \\
\hline $65 \mathrm{y}$ & $1.05(1.03-1.07)$ & 0.001 \\
\hline \multicolumn{3}{|c|}{ Sex } \\
\hline Male & $1.06(1.04-1.08)$ & 0.001 \\
\hline Female & $1.04(1.01-1.06)$ & 0.005 \\
\hline \multicolumn{3}{|c|}{ Ethnicity } \\
\hline Chinese & $1.05(1.03-1.07)$ & 0.001 \\
\hline Malay & $1.05(1.02-1.08)$ & 0.002 \\
\hline Indian & $1.04(1.01-1.08)$ & 0.014 \\
\hline \multicolumn{3}{|c|}{ Subtype } \\
\hline STEMI & $1.00(0.98-1.03)$ & 0.940 \\
\hline NSTEMI & $1.08(1.05-1.10)$ & 0.001 \\
\hline \multicolumn{3}{|c|}{ History of MI/CABG/PCI } \\
\hline Yes & $1.05(1.03-1.08)$ & 0.001 \\
\hline No & $1.05(1.03-1.07)$ & 0.001 \\
\hline \multicolumn{3}{|c|}{ History of diabetes mellitus } \\
\hline Yes & $1.06(1.04-1.08)$ & 0.001 \\
\hline No & $1.05(1.03-1.07)$ & 0.001 \\
\hline \multicolumn{3}{|c|}{ History of hypertension } \\
\hline Yes & $1.05(1.03-1.07)$ & 0.001 \\
\hline No & $1.06(1.04-1.09)$ & 0.001 \\
\hline \multicolumn{3}{|c|}{ History of hyperlipidemia } \\
\hline Yes & $1.05(1.03-1.08)$ & 0.001 \\
\hline No & $1.05(1.02-1.07)$ & 0.001 \\
\hline \multicolumn{3}{|c|}{ Current/former smoker } \\
\hline Yes & $1.04(1.02-1.07)$ & 0.001 \\
\hline No & $1.06(1.04-1.08)$ & 0.001 \\
\hline \multicolumn{3}{|c|}{ Place of MI onset } \\
\hline Inpatient & $1.13(1.09-1.16)$ & 0.001 \\
\hline Outpatient & $1.02(1.00-1.04)$ & 0.029 \\
\hline
\end{tabular}

Author Contributions: Conceptualization, K.H.C., A.F.W.H., and M.E.H.O.; supervision, K.H.C., A.F.W.H., and M.E.H.O. All authors carried out research, analyzed the results, and wrote the manuscript. All authors gave final approval for publication.

Funding: This study was supported by the Singapore University of Technology and Design (SUTD) Start-up Research Grant (SRG SCI 2019 142). K.H.C., J.W.L., and J.M.K. were supported by SUTD (SRG SCI 2019 142). A.F.W.H. was supported by the Khoo Clinical Scholars Programme, the Khoo Pilot Award (KP/2019/0034), Duke-NUS Medical School, and the National Medical Research Council (NMRC/CS_Seedfd/012/2018). M.E.H.O. reports funding from the Zoll Medical Corporation for a study involving mechanical cardiopulmonary resuscitation devices; grants from the Laerdal Foundation, Laerdal Medical, and the Ramsey Social Justice Foundation for funding of the Pan-Asian Resuscitation Outcomes Study; an advisory relationship with Global Healthcare SG, a commercial entity that manufactures cooling devices; and funding from Laerdal Medical on an observation program to their Community CPR Training Centre Research Program in Norway.

Acknowledgments: The authors would like to express thanks and gratitude to the medical team from the Department of Emergency Medicine, Singapore General Hospital. 
Conflicts of Interest: The authors declare no conflicts of interest. The funders had no role in the design of the study; in the collection, analyses, or interpretation of data; in the writing of the manuscript; or in the decision to publish the results.

\section{References}

1. The United Nations Economic Commission for Europe. Air pollution and health. Available online: https://www.unece.org/environmental-policy/conventions/envlrtapwelcome/cross-sectoral-linkages/ air-pollution-and-health.html. (accessed on 30 May 2019).

2. Lim, S.S.; Vos, T.; Flaxman, A.D.; Danaei, G.; Shibuya, K.; Adair-Rohani, H.; Amann, M.; Anderson, H.R.; Andrews, K.G.; Aryee, M.; et al. A comparative risk assessment of burden of disease and injury attributable to 67 risk factors and risk factor clusters in 21 regions, 1990-2010: A systematic analysis for the Global Burden of Disease Study 2010. Lancet (London, England) 2012, 380, 2224-2260. [CrossRef]

3. Liu, J.C.; Pereira, G.; Uhl, S.A.; Bravo, M.A.; Bell, M.L. A systematic review of the physical health impacts from non-occupational exposure to wildfire smoke. Environ. Res. 2015, 136, 120-132. [CrossRef]

4. World Health Organization. Burden of disease from ambient air pollution for 2016. Available online: https://www.who.int/airpollution/data/AAP_BoD_results_May2018_final.pdf (accessed on 1 May 2019).

5. Betha, R.; Behera, S.N.; Balasubramanian, R. 2013 Southeast Asian Smoke Haze: Fractionation of Particulate-Bound Elements and Associated Health Risk. Environ. Sci. Technol. 2014, 48, 4327-4335. [CrossRef]

6. Sastry, N. Forest Fires, Air Pollution, and Mortality in Southeast Asia. Demography 2002, 39, 1-23. [CrossRef]

7. Sunchindah, A. Transboundary haze pollution problem in Southeast Asia: Reframing ASEAN's response (no. DP-2015-82). Available online: http://www.eria.org/ERIA-DP-2015-82.pdf (accessed on 1 May 2019).

8. Marlier, M.E.; DeFries, R.S.; Voulgarakis, A.; Kinney, P.L.; Randerson, J.T.; Shindell, D.T.; Chen, Y.; Faluvegi, G. El Niño and health risks from landscape fire emissions in Southeast Asia. Nat. Clim. Chang. 2013, 3, 131-136. [CrossRef]

9. Odihi, J.O. Haze and Health in Brunei Darussalam: The Case of the 1997-98 Episodes. Singap. J. Trop. Geogr. 2001, 22, 38-51. [CrossRef]

10. Reddington, C.L.; Yoshioka, M.; Balasubramanian, R.; Ridley, D.; Toh, Y.Y.; Arnold, S.R.; Spracklen, D. V Contribution of vegetation and peat fires to particulate air pollution in Southeast Asia. Environ. Res. Lett. 2014, 9, 094006. [CrossRef]

11. Ramakreshnan, L.; Aghamohammadi, N.; Fong, C.S.; Bulgiba, A.; Zaki, R.A.; Wong, L.P.; Sulaiman, N.M. Haze and health impacts in ASEAN countries: A systematic review. Environ. Sci. Pollut. Res. 2018, 25, 2096-2111. [CrossRef]

12. Koplitz, S.N.; Mickley, L.J.; Marlier, M.E.; Buonocore, J.J.; Kim, P.S.; Liu, T.; Sulprizio, M.P.; DeFries, R.S.; Jacob, D.J.; Schwartz, J.; et al. Public health impacts of the severe haze in Equatorial Asia in September-October 2015: Demonstration of a new framework for informing fire management strategies to reduce downwind smoke exposure. Environ. Res. Lett. 2016, 11, 094023. [CrossRef]

13. Pavagadhi, S.; Betha, R.; Venkatesan, S.; Balasubramanian, R.; Hande, M.P. Physicochemical and toxicological characteristics of urban aerosols during a recent Indonesian biomass burning episode. Environ. Sci. Pollut. Res. 2013, 20, 2569-2578. [CrossRef]

14. Ward, D.E. Factors Influencing the Emissions of Gases and Particulate Matter from Biomass Burning. In Fire in the Tropical Biota. Ecological Studies (Analysis and Synthesis); Goldammer, J., Ed.; Springer: Berlin/Heidelberg, Germany, 1990; Volume 84, pp. 418-436.

15. Khan, M.F.; Latif, M.T.; Saw, W.H.; Amil, N.; Nadzir, M.S.M.; Sahani, M.; Tahir, N.M.; Chung, J.X. Fine particulate matter in the tropical environment: Monsoonal effects, source apportionment, and health risk assessment. Atmos. Chem. Phys. 2016, 16, 597-617. [CrossRef]

16. Abba, E.J.; Unnikrishnan, S.; Kumar, R.; Yeole, B.; Chowdhury, Z. Fine aerosol and PAH carcinogenicity estimation in outdoor environment of Mumbai City, India. Int. J. Environ. Health Res. 2012, 22, 134-149. [CrossRef]

17. Reid, C.E.; Brauer, M.; Johnston, F.H.; Jerrett, M.; Balmes, J.R.; Elliott, C.T. Critical Review of Health Impacts of Wildfire Smoke Exposure. Environ. Health Perspect. 2016, 124, 1334-1343. [CrossRef] 
18. Yeo, B.; Liew, C.F.; Oon, H.H. Clinical Experience and Impact of a Community-Led Volunteer Atmospheric Haze Clinic in Singapore. Southeast Asian J. Trop. Med. Public Health 2014, 45, 1448-1453.

19. TAN, W.C.; QIU, D.; LIAM, B.L.; NG, T.P.; LEE, S.H.; van EEDEN, S.F.; D'YACHKOVA, Y.; HOGG, J.C. The Human Bone Marrow Response to Acute Air Pollution Caused by Forest Fires. Am. J. Respir. Crit. Care Med. 2000, 161, 1213-1217. [CrossRef]

20. Ho, R.C.; Zhang, M.W.; Ho, C.S.; Pan, F.; Lu, Y.; Sharma, V.K. Impact of 2013 south Asian haze crisis: Study of physical and psychological symptoms and perceived dangerousness of pollution level. BMC Psychiatry 2014, 14, 81. [CrossRef]

21. Tan, B.Y.; Leong, A.Z.; Leow, A.S.; Ngiam, N.J.; Ng, B.S.; Sharma, M.; Yeo, L.L.; Seow, P.A.; Hong, C.S.; Chee, Y.H.; et al. Psychosomatic symptoms during South East Asian haze crisis are related to changes in cerebral hemodynamics. PLoS ONE 2019, 14, e0208724. [CrossRef]

22. Emmanuel, S.C. Impact to lung health of haze from forest fires: The Singapore experience. Respirology 2000, 5, 175-182. [CrossRef]

23. Frankenberg, E.; McKee, D.; Thomas, D. Health Consequences of Forest Fires in Indonesia. Demography 2005, 42, 109-129. [CrossRef]

24. Mott, J.A.; Mannino, D.M.; Alverson, C.J.; Kiyu, A.; Hashim, J.; Lee, T.; Falter, K.; Redd, S.C. Cardiorespiratory hospitalizations associated with smoke exposure during the 1997 Southeast Asian forest fires. Int. J. Hyg. Environ. Health 2005, 208, 75-85. [CrossRef]

25. Chew, F.T.; Ooi, B.C.; Hui, J.K.; Saharom, R.; Goh, D.Y.; Lee, B.W. Singapore's haze and acute asthma in children. Lancet (London, England) 1995, 346, 1427. [CrossRef]

26. Hashim J., H.; Hashim, Z.; Jalaludin, J.; Lubis, S.H.; Hashim, R. Respiratory function of elementary school children exposed to the 1997 Kuala Lumpur Haze. Epidemiology 1998, 9, 103. [CrossRef]

27. Andersen, Z.J.; Kristiansen, L.C.; Andersen, K.K.; Olsen, T.S.; Hvidberg, M.; Jensen, S.S.; Ketzel, M.; Loft, S.; Sørensen, M.; Tjønneland, A.; et al. Stroke and Long-Term Exposure to Outdoor Air Pollution from Nitrogen Dioxide. Stroke 2012, 43, 320-325. [CrossRef]

28. Xiang, H.; Mertz, K.J.; Arena, V.C.; Brink, L.L.; Xu, X.; Bi, Y.; Talbott, E.O. Estimation of Short-Term Effects of Air Pollution on Stroke Hospital Admissions in Wuhan, China. PLoS ONE 2013, 8, e61168. [CrossRef]

29. Szyszkowicz, M.; Stieb, D.M.; Rowe, B.H. Air pollution and daily ED visits for migraine and headache in Edmonton, Canada. Am. J. Emerg. Med. 2009, 27, 391-396. [CrossRef]

30. Szyszkowicz, M.; Kaplan, G.G.; Grafstein, E.; Rowe, B.H. Emergency department visits for migraine and headache: A multi-city study. Int. J. Occup. Med. Environ. Health 2009, 22, 235-242. [CrossRef]

31. Chen, C.-C.; Tsai, S.-S.; Yang, C.-Y. Association between Fine Particulate Air Pollution and Daily Clinic Visits for Migraine in a Subtropical City: Taipei, Taiwan. Int. J. Environ. Res. Public Health 2015, 12, 4697-4708. [CrossRef]

32. Chang, C.-C.; Chiu, H.-F.; Yang, C.-Y. Fine particulate air pollution and outpatient department visits for headache in Taipei, Taiwan. J. Toxicol. Environ. Health. A 2015, 78, 506-515. [CrossRef]

33. Ho, A.F.W.; Zheng, H.; De Silva, D.A.; Wah, W.; Earnest, A.; Pang, Y.H.; Xie, Z.; Pek, P.P.; Liu, N.; Ng, Y.Y.; et al. The Relationship Between Ambient Air Pollution and Acute Ischemic Stroke: A Time-Stratified Case-Crossover Study in a City-State with Seasonal Exposure to the Southeast Asian Haze Problem. Ann. Emerg. Med. 2018, 72, 591-601. [CrossRef]

34. Chongsuvivatwong, V.; Phua, K.H.; Yap, M.T.; Pocock, N.S.; Hashim, J.H.; Chhem, R.; Wilopo, S.A.; Lopez, A.D. Health and health-care systems in southeast Asia: Diversity and transitions. Lancet 2011, 377, 429-437. [CrossRef]

35. Du, Y.; Xu, X.; Chu, M.; Guo, Y.; Wang, J. Air particulate matter and cardiovascular disease: The epidemiological, biomedical and clinical evidence. J. Thorac. Dis. 2016, 8, E8-E19.

36. Cheong, K.H.; Ho, A.F.W.; Zheng, H.; Earnest, A.; Pek, P.P.; Seok, J.Y.; Chan, S.K.T.; Liu, N.; Tan, J.W.C.; Wong, T.H.; et al. Significant Association between Transboundary Air Pollution and Acute Myocardial Infarction. J. Am. Coll. Cardiol. 2019, 73, 248. [CrossRef]

37. Ho, A.F.W.; Zheng, H.; Earnest, A.; Cheong, K.H.; Pek, P.P.; Seok, J.Y.; Liu, N.; Kwan, Y.H.; Tan, J.W.C.; Wong, T.H.; et al. Time-Stratified Case Crossover Study of the Association of Outdoor Ambient Air Pollution With the Risk of Acute Myocardial Infarction in the Context of Seasonal Exposure to the Southeast Asian Haze Problem. J. Am. Heart Assoc. 2019, 8, e011272. [CrossRef] 
38. Yap, J.; Ng, Y.; Yeo, K.K.; Sahlén, A.; Lam, C.S.P.; Lee, V.; Ma, S. Particulate air pollution on cardiovascular mortality in the tropics: impact on the elderly. Environ. Health 2019, 18, 34. [CrossRef]

39. Yang, C.; Peng, X.; Huang, W.; Chen, R.; Xu, Z.; Chen, B.; Kan, H. A time-stratified case-crossover study of fine particulate matter air pollution and mortality in Guangzhou, China. Int. Arch. Occup. Environ. Health 2012, 85, 579-585. [CrossRef]

40. Sahani, M.; Zainon, N.A.; Wan Mahiyuddin, W.R.; Latif, M.T.; Hod, R.; Khan, M.F.; Tahir, N.M.; Chan, C.-C. A case-crossover analysis of forest fire haze events and mortality in Malaysia. Atmos. Environ. 2014, 96, 257-265. [CrossRef]

41. Martinelli, N.; Olivieri, O.; Girelli, D. Air particulate matter and cardiovascular disease: A narrative review. Eur. J. Intern. Med. 2013, 24, 295-302. [CrossRef]

42. Ho, A.F.W.; Bte Mohd Yazid, S.N.N.; Zheng, H.; Earnest, A.; Ng, Y.Y.; Liu, N.; Lam, S.S.W.; Ong, M.E.H.; Koh, J.M.; Cheong, K.H. Effects of Air Pollution and Other Environmental Parameters on All-Cause Mortality in Singapore. Circulation 2018, 138, A12831.

43. Mishra, D.; Goyal, P.; Upadhyay, A. Artificial intelligence based approach to forecast PM2.5 during haze episodes: A case study of Delhi, India. Atmos. Environ. 2015, 102, 239-248. [CrossRef]

44. Gogikar, P.; Tyagi, B.; Gorai, A.K. Seasonal prediction of particulate matter over the steel city of India using neural network models. Modeling Earth Syst. Environ. 2019, 5, 227-243. [CrossRef]

(C) 2019 by the authors. Licensee MDPI, Basel, Switzerland. This article is an open access article distributed under the terms and conditions of the Creative Commons Attribution (CC BY) license (http://creativecommons.org/licenses/by/4.0/). 